\title{
The role played by supply chain strategies and supply chain integration in financial performance. An empirical study in Peru
}

\author{
PÉREZ GILABERT, FRANCISCO AlEJANDRo \\ Pontificia Universidad Católica del Perú \\ Correo electrónico: perezg.francisco@pucp.edu.pe \\ PENA ACEVEDo, JoRge LUIS \\ Pontificia Universidad Católica del Perú \\ Correo electrónico: jorge.pena@pucp.edu.pe
}

\begin{abstract}
The objective of this study is to develop and test a framework for the role that supply chain strategy (SCS) and supply chain integration have in a firm's financial performance and to increase the understanding of the role that these factors play in supply chain design. Structural equation modeling was used to test these relationships based on data obtained from small and medium exporting enterprises in Peru. This study responds to a gap in understanding the role of supply chains in small and medium enterprises (SMEs) and how firms in Latin America, especially in Peru, apply supply chain concepts. Findings indicate that companies should prioritize their integration efforts depending on the type of supply chain strategy. Likewise, results show that customer integration is directly related to a firm's financial performance. This study responds to the need to understand the development of supply chain strategies and the generation of competitive advantage in Peruvian export-manufacturing SMEs.
\end{abstract}

Keywords: small and medium enterprises, structural equation modeling, supply chain strategies, supply chain integration, financial performance.

JEL classification: C44; L00; L60; N66.

MSC2010: 90B70; 62H15; 62P25; 62P30; 62J99. 


\title{
El papel que juegan las estrategias y la integración de la cadena de suministro en el desempeño financiero. Un estudio empírico en Perú
}

\begin{abstract}
RESUMEN
El objetivo de este estudio es desarrollar y probar un marco para el papel que las estrategias de la cadena de suministro (SCS) y la integración de la cadena de suministro tienen del rendimiento financiero de una empresa y aumentar la comprensión del papel que estos factores tienen en el diseño de la cadena de suministro. Se utilizó la modelización de ecuaciones estructurales para probar estas relaciones a partir de datos tomados de pequeñas y medianas empresas (PYMES) exportadoras peruanas. Nuestro estudio responde a un vacío en la comprensión del papel de la cadena de suministro en las PYME, así como a llenar el vacío de cómo las empresas en América Latina, especialmente en Perú, aplican los conceptos de la cadena de suministro. Los resultados indican que las empresas deben priorizar su esfuerzo de integración dependiendo del tipo de estrategia de la cadena de suministro. Asimismo, los resultados muestran que la integración de los clientes está directamente relacionada con el rendimiento financiero de la empresa. Este estudio responde a la necesidad de encontrar respuestas al desarrollo de estrategias de cadena de suministro y a la generación de ventajas competitivas en las PYMES exportadoras peruanas.
\end{abstract}

Palabras clave: pequeñas y medianas empresas, modelos de ecuaciones estructurales, estrategias de la cadena de suministro, integración de la cadena de suministro, rendimiento financiero.

Clasificación JEL: C44; L00; L60; N66.

MSC2010: 90B70; 62H15; 62P25; 62P30; 62J99.

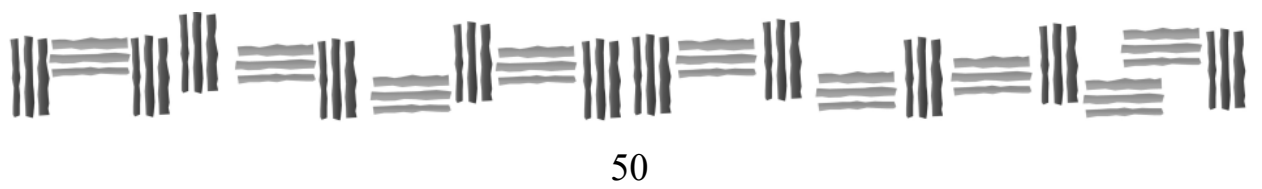




\section{Introduction}

Since the 1980s, Latin American economies have opened their markets to the outside world through an accelerated expansion of exports and imports (Urmeneta, 2016). This expansion has been the result of the adoption of strategies that have considered economies' resources and capabilities (Araya, 2016). However, many challenges persist in the region, with companies facing problems such as poor infrastructure, expensive and inefficient logistic networks, and lack of economic integration (Tanco et al., 2018). These challenges have resulted in supply chain management being less studied and therefore less understood in Latin American countries, especially in those aspects related to supply chain integration and their impact on the financial performance of an organization (Ruiz-Torres et al., 2012). Thus, it is interesting and instructive to study the role of supply chain strategies in companies in an emerging Latin American market like Peru. Peruvian companies are interested in understanding the concepts associated with supply chain strategies and the strategic role they must adopt to position themselves on a par with their international competitors and thus be able to compete globally. Detailed analysis of the development of supply chain strategies in large companies in the country can help determine the low level of development of these strategies compared to international companies (Roncal, 2019).

Factors such as barriers to entry, product differentiation, and vertical integration affect a company's ability to successfully integrate internally and externally and thereby improve the organization. This integration with supply chain partners better reflects the current reality of the business environment and expands the list of structural foundations that researchers can study to measure the impact of the company (Ralston et al., 2015). Ralston et al. pointed out that relationships in a supply chain require cross-functional and cross-firm business processes; therefore, it is important to generate confidence among all links in the chain by building long-term relationships, nurturing frequent communication, and making joint decisions.

Several studies have been conducted on supply chain integration; however, this is an evolving construct (Huo et al., 2014) with no consensus as to which components to include nor how to measure them (Marin-Garcia et al., 2014). Qi et al. (2017) developed an integrated framework based on the impact that operational strategies, as well as supply chain strategies, have on the integration and performance of organizations. This study was conducted on SMEs in China and included the four types of operational strategies (OS) developed by Skinner (1969). In addition, it included the generic supply chain strategies (SCS), studied by Fisher (1997), and supply chain integration (SCI), considering the variables internal and external integration (Huo et al., 2014). The work of Qi et al. (2017) is limited because several authors have recognized the need to further divide external integration into two constructs: integration with clients and integration with suppliers (Alfalla-Luque \& Medina-López, 2009; Flynn et al., 2010; Won Lee et al., 2007). Schoenherr and Swink (2012) noted that integration between suppliers and customers allows companies to manage the flow of goods through the entire supply chain efficiently while providing access to resources and capabilities in chain partners that would otherwise have been very costly to develop. The seminal work of Frohlich and Westbrook (2001a) detailed an early concept of supply chain integration and developed the concept of integration arcs; they concluded that a comprehensive external integration strategy involving supplier and customer relationships will outperform other integration strategies.

There is a bias in supply chain management (SCM) studies towards large-scale organizations with small businesses acting as first and second suppliers (Thakkar \& Deshmukh, 2008), but many of these organizations are dependent on small and medium enterprises (SMEs). Thus, further study is needed of how SMEs apply and develop concepts from SCM, especially in Latin America where research in this area is lacking (Tanco et al., 2018). There is no doubt that SMEs face much more competitive markets than large-scale organizations. Although business strategies may be similar in both cases, it is no less true that the former must develop much more agile resources and dynamic capabilities in a context where several elements interact (Rodríguez \& Figueroa, 2013). 
In this study, we used a quantitative approach of deductive logic with a nonexperimental, crosssectional, and explanatory design that allowed correlating the constructs of supply chain strategies, supply chain integration, and the financial performance of organizations to determine the correlation that exists between the independent variables and the dependent variable. The data necessary for our approach was collected from SMEs in Peru. A structural equation model was used to determine, through confirmatory factor analysis and regression analysis, whether the proposed model is adequate to analyze the structural paths among the constructs.

The contribution of this paper is twofold. First, we expand the framework developed by Qi et al. (2017) by dividing external integration into two constructs: integration with clients and integration with suppliers. Second, we expand SCM research in Latin America and the study of SCM practices in SMEs, showing how by using robust methodologies, SMEs can validate factors of supply chain strategy (SCS) and its relationship with organizational performance, enabling decision makers in Peruvian SMEs to understand how the theory of dynamic resources and capabilities can contribute to better results in their operations.

\section{Literature Review}

Since Skinner's (1969) seminal work, much research has been done on the operational strategy (OS) of firms. Skinner's original research takes into consideration four strategies: cost quality, delivery and flexibility. OS has been studied extensively in relation to the environment, managerial choices, and competitive strategies (Qi et al., 2017). Qi et al. pointed out that, although OS has been understood from an organization-wide perspective, new evolving practices and theories require a new understanding of OS in the context of supply chain strategies.

In developing operational strategies, companies should identify their customers' needs for different products and services, classifying these into order winners, to differentiate themselves from competitors, or order qualifiers, to serve the market (Qi et al., 2017). Based on these needs, companies should build operational infrastructures and capabilities accordingly, such as the development of supply chain, management infrastructures, and capabilities; therefore, following the organization's operational strategies, the development of a supply chain strategy is necessary (Qi et al., 2017). Operational and supply chain strategies are dynamic capabilities that can help companies to repetitively perform productive tasks related to the transformation of raw materials into finished products.

According to Qi et al. (2017), supply chain management requires strategies and practices beyond the boundaries of companies such as the relationship of OS with knowledge management (Hussain et al., 2015), with competitive strategies (Shavarini et al., 2013), and with competitive advantage (Liu \& Liang, 2015). However, very few studies have been conducted from the perspective of supply chain management, its integration into, and its impact on organizational financial performance (Qi et al., 2017). An example is the study by Quesada et al. (2008), who analyzed the strategic alignment between order winner selection and supply chain integration strategies. There is, therefore, a call for further research on the role of operational strategies in the formation of supply chain strategies, their integration, and organizational performance (Qi et al., 2017).

Flynn et al. (2010) noted the high degree of overlap between definitions of integration that address the flow of materials, information, resources, and/or money. They proposed, following the understanding of Saeed et al. (2005), that the management of supply chain integration (SCI) can be understood from the perspective of two dimensions: internal integration (II), which describes the level of collaboration of functions within a manufacturer, and external integration (EI), which reveals the characteristics of close and interactive relationships with customers and suppliers.

Supply chain integration can be viewed as a dynamic capability of the organization. According to organizational capability theory, the capabilities of supply chain strategies can be transferred to 
supply chain integration capabilities (Huo, 2012). On the other hand, according to Qi et al. (2017), the vision of supply chains defined by their strategies can develop communication, process coordination, and joint planning between functions and external supply chain partners. At the same time, learning capabilities formed in the development of supply chain strategies can also help companies establish integrative relationships between functions and chain partners (Qi et al., 2017).

Supply chain integration can be defined as the degree to which an organization strategically collaborates with internal functions or external supply chain members to manage the intra and interorganizational processes essential to achieve an efficient and effective flow of products, services, information, money, and decisions in order to deliver maximum value to the customer (Zhao et al., 2008). Internal integration and external integration, understood by some authors as integration with suppliers and customers, play totally different roles in organizations. While the former states that a company's departments should function in an integrated manner, the latter highlights the importance of establishing a close relationship with supply chain partners, that is, customers and suppliers (Qi et al., 2017).

Internal integration refers to the degree to which a manufacturing company structures its organizational strategies, practices, and processes into organizational and collaborative processes in order to meet the requirements of its customers and interact efficiently with its suppliers (Flynn et al., 2010). Two key features of internal integration are communication by information sharing, in which a firm's departments outline a system for efficient information sharing, and cooperation by joint decision making, in which important firm decisions are in collaboration with all the departments (Ellinger et al., 2000; Jajja et al., 2018). Flynn et al. (2010) pointed out that external integration, on the other hand, refers to the degree to which a manufacturer relates to its customers and suppliers to structure strategies and practice collaborative and synchronized processes for mutual value (Chen \& Paulraj, 2004).

External integration can be divided into customer integration and supplier integration. Customer integration is the concept related to planning, implementing, and evaluating successful relationships between recipients either upstream or downstream of supply chain (Jajja et al., 2018). Customer integration is primarily concerned with the ability to deliver the right products and services at the right time, in the right place, and in the right quantity. This means integration of the customer in processes such as idea generation, product management, and delivery (Koufteros et al., 2005). Supplier integration, on the other hand, deals with strategic linkages with suppliers (Jajja et al., 2018). This requires involving suppliers in the product development process, as well as in production planning and inventory management. Supplier integration seeks to develop a rapid response system with suppliers, constructing a supplier network that assures reliable delivery and exchanging information with suppliers. This relationship cannot be completed if the firm does not consider key suppliers as strategic collaborators and does not help develop their technological and managerial capabilities (Jajja et al., 2016).

Extensive literature has found that supply chain integration is the driver of the financial performance of firms (Acar et al., 2006; Huh et al., 2008; Qi et al., 2017; Saini \& Johnson, 2005). Qi et al. (2017) pointed out that both internal integration and external integration are positively related to financial performance. On the other hand, information sharing is related to the financial performance of firms (Huo et al., 2014). The ability to exchange information is an antecedent of collaborative buyersupplier relationships and also impacts a firm's financial performance (Hsu et al., 2008).

\section{Hypothesis Development}

The basic objective of the lean supply chain strategy is to provide a flow of goods, services, and technologies from suppliers to customers without creating any waste (Jasti \& Kodali, 2015). This means that the competitive focus of the lean supply chain strategy is to reduce costs. Therefore, it is imperative for lean enterprises to organize an efficient production system that is integrated with the company's 
logistics processes, thus producing high volumes of output at low cost (Qi et al., 2017). Such a high volume of production requires high efficiency through automation and real-time information flow within the organization. Therefore, the following hypothesis is proposed:

\section{H1: Lean supply chain strategy (LSCS) is positively related to internal integration (II).}

Lean supply chain manufacturers must maintain good relationships with their suppliers to ensure the availability of raw materials (Qrunfleh \& Tarafdar, 2013). It has also been emphasized that a close and long relationship with few suppliers is one of the characteristics of lean supply chains (Jacobs et al., 2014). A lean supply chain also requires a high degree of communication with its customers, thus improving the accuracy of the demand information exchanged, thereby reducing inventory obsolescence (Qi et al., 2017). Therefore, the following hypotheses are proposed:

H2: Lean supply chain strategy (LSCS) is positively related to customer integration (CI).

H3: Lean supply chain strategy (LSCS) is positively related to supplier integration (SI).

An agile supply chain emphasizes market responsiveness and rapid response to the customer. For these elements to be provided, process and functional integration should be enhanced through the use of advanced manufacturing and information technologies (Gunasekaran \& Yusuf, 2002). In addition, agile supply chains can quickly transfer customer demands to all functions of the manufacturer, thus facilitating real-time connections through technologies and information systems (Roh et al., 2014). Companies with agile supply chains are able to form teams to effectively resolve conflicts, problems, and errors that may arise within the company (Qrunfleh \& Tarafdar, 2013). Therefore, the following hypothesis is proposed:

H4: Agile supply chain strategy (ASCS) is positively related to internal integration (II).

An agile supply chain could respond quickly to changes in demand, in terms of volume and variety, to serve volatile and unpredictable markets (Christopher, 2000). It is no longer sufficient to respond quickly and at the right time, so agility plays an important role as a significant further step in responding to the demand changes outlined above. An agile supply chain is also determined by the consistent and timely receipt of the right number of parts from multiple suppliers (Ahmad \& Schroeder, 2001). Agile supply chains push companies to integrate with external partners, customers, and suppliers in the chain, thus generating opportunities and quickly detecting changes in customer demand. Therefore, the following hypotheses are proposed:

H5: Agile supply chain strategy (ASCS) is positively related to customer integration (CI).

H6: Agile supply chain strategy (ASCS) is positively related to supplier integration (SI).

According to capability theory, supply chain integration is necessary for financial performance; this is because integration facilitates information sharing and therefore enables firms to cope with environmental uncertainty (Huo, 2012). Verona (1999) proposed that both internal and external integration capabilities improve process efficiency and product effectiveness. However, Verona could not empirically verify this relationship. According to Qi et al. (2017), an extensive literature has determined the relationship of supply chain integration to financial performance (Flynn et al., 2010; Kim, 2009). Internal supply chain integration was identified as one of the important differentiators of firm performance; other studies have found a relationship between internal integration and financial performance (Stank et al., 2001). Therefore, the following hypothesis is proposed:

$H 7$ : Internal integration (II) is positively related to supplier integration (SI).

The impact of the relationship between customer integration and financial performance is inconsistent (Huo, 2012). While some studies such as Flynn et al. (2010) found no significant 
relationship between these two constructs, others such as Qi et al. (2017) and Narasimhan and Kim (2002) reported positive effects. On the other hand, Frohlich and Westbrook (2001b) found that firms with higher supplier integration achieve higher levels of market share and financial returns. Likewise, Huo et al. (2013) found that supplier integration through system and process integration have a positive effect on the financial performance of Chinese firms. Other studies have found a mediating role of supplier integration on financial performance through other constructs such as operational performance and flexibility (Shou et al., 2018). Therefore, the following hypotheses are proposed:

H8: Customer integration (CI) is positively related to financial performance.

H9: Supplier integration (SI) is positively related to financial performance.

The following theoretical framework is proposed for supply chain strategies, supply chain integration, and financial performance (Figure 1).

Figure 1. Theoretical Framework for the relationship between Supply Chain Strategies and Supply Chain Integration and Financial Performance.

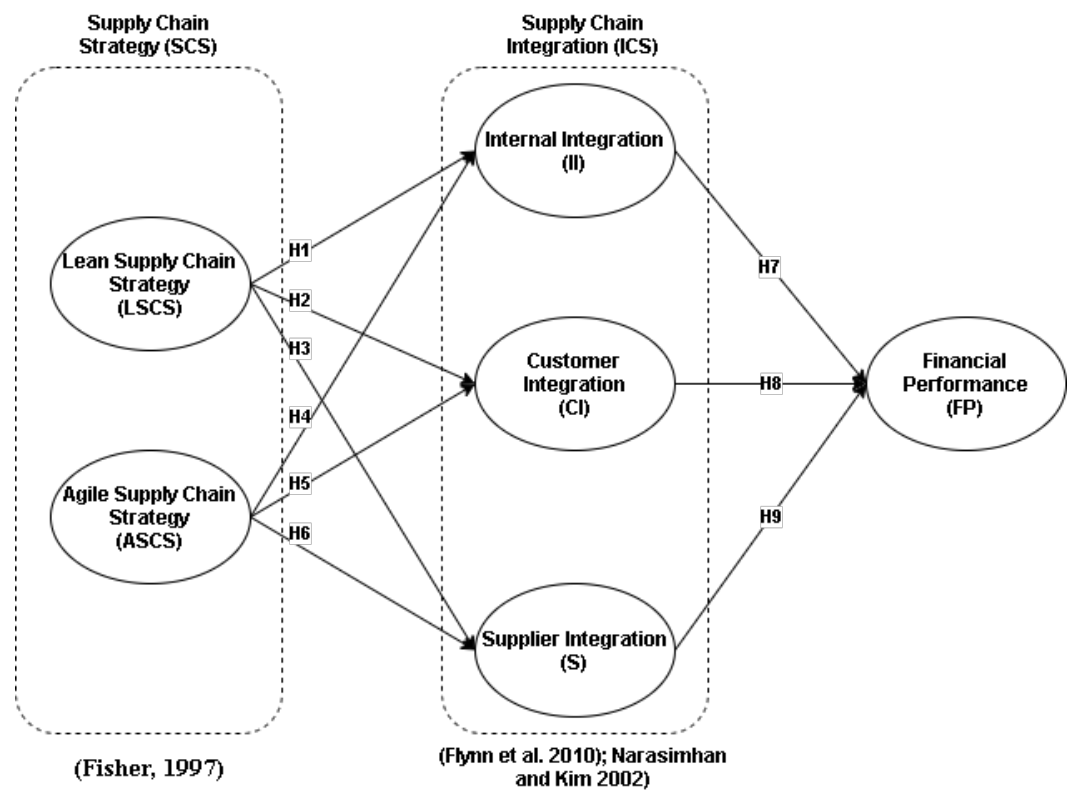

\section{Research Methodology}

This study used a quantitative, deductive logic approach, with a nonexperimental, cross-sectional, explanatory design that allowed correlating the constructs of supply chain strategies (lean and agile), supply chain integration (internal, customer, and supplier integration), as part of the SCI construct, as well as the organization's financial performance. The research design included the phases of instrument selection, data collection, and data analysis.

\subsection{Instrumentation}

Original questionnaires were in English, so the back translation methodology was used. Questionnaires were translated by a professional translator in the area of this research. After translating the questions from English to Spanish, they were checked for validity and fit by a panel of experts composed of researchers from universities in Peru and Ecuador and experts in supply chain management. The final version in Spanish was again translated into English for verification (Flynn et al., 2010). 
The independent variables comprised the supply chain strategy (lean and agile) and were measured using the instrument adopted by Ward et al. (1995); in the case of the variables customer integration, integration with suppliers, and internal integration, the instruments used by Narasimhan and Kim (2002) were used; instruments developed by De Toni and Tonchia (2001) and Vickery et al. (2003) were used for measurement of the dependent variable (Table A1 in the Appendix A). For the operationalization of the factors that make up the conceptual model, a 7-point Likert scale was chosen. This scale has been previously used in the literature and has demonstrated validity and reliability. The results of this research seek to be representative of Peruvian export-manufacturing SMEs. The sampling technique used was non-probabilistic and by convenience because the response rate is low as most managers are not willing to participate in this type of research (Manosalvas, 2018).

\subsection{Data Collection}

Urmeneta (2016) introduced the concept of export SMEs, which was the basis for defining the population of this research. According to Urmeneta, export companies are all those that comply with customs procedures to ship abroad. However, it is difficult to obtain a single definition and comparable data on firms by size in Latin America and the Caribbean because in most countries in the region, there are multiple and divergent definitions. Urmeneta pointed out that definitions may vary according to the economic sector, the institution in question, and of course, the year; in addition, the definitions consider different variables to measure size, such as the value of sales or equity in local currency, which become obsolete in the short term.

The variable of the number of workers per company seems to be the most practical for defining the size of the company and the one that best reflects the reality of each country (Urmeneta, 2016). Table 1 details the different variables and the classification of companies, small and medium-sized for the case of Peru; micro SMEs have been left out of this study due to their high level of informality (50.4\%) and low level of exports (Garcés \& Landa, 2019). The total population of Peruvian exporting companies is $N=8200$ companies. This value coincides with studies carried out on the development of export companies in recent years, where it is mentioned that Peru would have 8200 export companies with their shipments exceeding 44 billion USD in 2019 (SIPC Market Intelligence, 2019).

Table 1. Criteria used to define Export SMEs.

\begin{tabular}{lcccc}
\hline & \multicolumn{2}{l}{ Total annual sales (USD) } & Number of workers & \\
\hline SME Type & From & To & From & To \\
\hline Large SME & 3059001 & - & 251 & - \\
Medium SME & 2261001 & 3059000 & 51 & 250 \\
Small SME & 199500 & 2261000 & 11 & 50 \\
\hline Sour & Adapted from Dinámica de las empresas exportadoras en América Latina: El aporte de
\end{tabular}

Source: Adapted from Dinámica de las empresas exportadoras en América Latina: El aporte de las PYMES, by R. Urmeneta, 2016, CEPAL, https://www.cepal.org/es/publicaciones/40296dinamica-empresas-exportadoras-america-latina-aporte-pymes

In this research, export SMEs were considered because they allow the analysis of the concepts related to SCS, SCI, and financial performance of the organization. On the other hand, as mentioned by Humphrey and Schmitz (2002), export companies compete in open markets, so the concepts related to SCS and SCI are more developed in this type of company than in non-exporting SMEs that compete only in their local markets. 
The study combines both primary and secondary data. The primary data were obtained through on-site surveys. The secondary data were obtained from the database of the web page of Peru's International Standard Industrial Classification of All Economic Activities (United Nations Department of Economic and Social Affairs, Statistics Division, 2008). To ensure the quality and understanding of the topic to be surveyed, each company received prior training from the researcher who, in turn, participated in part of the pilot test conducted in Peru between January and February 2020. The data collection process was delayed by the beginning of the confinement of all Peruvian households and the almost total suspension of manufacturing activities due to the COVID19 pandemic; there was not a significant number of responses to the online surveys, and it was necessary to wait for the return of key informants to the companies to start the data-collection process.

Companies contacted were those that fall within the ISIC REV. 4.0 and are classified as follows: C.10 (food product manufacturing); C.13 (textile manufacturing); C.15 (leather manufacturing); C.17 (manufacture of paper products); C.19 (manufacture of petroleum-related products); C.20 (manufacture of chemicals); C.21 (manufacture of pharmaceuticals); C.22 (manufacture of rubber and plastic products); C.23 (manufacture of nonmetallic mineral products); C.24 (manufacture of base metals); C.25 (manufacture of fabricated metal products); C.26 (manufacture of computer, electronic, and optical products); C.27 (manufacture of electrical equipment); C.28 (manufacture of machinery and equipment); C.29 (manufacture of motor vehicles, trailers, and semi-trailers); C.30 (manufacture of other transportation equipment); C.31 (manufacture of furniture); and C.33 (repair and installation of machinery and equipment).

The unit of analysis was limited to export-manufacturing SMEs in Peru, with exports in the last three years and that have made at least one export per year. The method of response used in this study was single respondent, in this case, operations managers, supply chain managers, CEOs, or administrators. Although a debate exists on whether single respondent surveys are appropriate to study supply chain management (Kull et al., 2018), several authors have pointed out that single respondent surveys might be more appropriate in the case of SMEs. Research suggests that SMEs have different and more diverse goals than larger firms and that SMEs are mostly owned by a single founder or founding family with specific goals and objectives for the firm (La Porta et al., 1999). Thus, SMEs having multiple respondents per survey might impede research as everyone on the organizational ladder might not be aware of or aligned with the single founder or founding family's vision. Likewise, multirespondent designs might exclude SMEs from supply chain management research and create a bias in the field towards large organizations that exclude new avenues of research in supply chain management theory (Kull et al., 2018). Finally, it has been found that in family businesses, as is the case with SMEs, single respondent surveys have similar regression results compared to multi-respondent surveys (Holt et al., 2017).

Based on the above definition, companies that exported only raw materials were not included. Through the website of Peru's ISIC REV. 4.0, only 682 companies met the profile of exporting SMEs. From the initial list of companies, a sample of 242 companies was obtained, representing a response rate of about $35.48 \%$. Only one response was obtained for each company because the surveys were directed to operations managers, supply chain managers, or the owners or administrators of the companies that agreed to participate in the study.

The data analysis was defined in two independent but sequential processes. The first was exploratory data analysis, using SPSS v.23 software. In this process, the quality of the data was confirmed as no missing values were found. Outliers were found and analyzed on a case-to-case basis; no problem was found, so they were kept in the study. In this first part, the descriptive analysis of the sample was performed by relating the qualitative variables and testing their degree of dependence with the chi-square test. Secondly, the methodology for data treatment was developed for structural equation modeling (SEM), using SPSS v.23 and AMOS v.23 software. Subsequently, the number of factors or latent variables, both endogenous and exogenous, and their corresponding items defined in the theoretical framework were defined. The confirmatory factor analysis (CFA) path graph was 
constructed, and the multivariate normality assumption was tested using Mardia's test; considering the threshold of a kurtosis index is greater than 70 , it was found that this assumption is not met.

For the parameter estimation procedure, there are some techniques which depend on the normality assumption indicated above; if multivariate normality is met, the maximum likelihood (ML) procedure is suggested; otherwise the unweighted least squares (ULS) procedure is recommended (Forero et al., 2009; Yang-Wallentin et al., 2010). The fit indicators of the measurement model were then verified according to the ULS procedure. The path graph of the SEM was constructed, and its indicators were found to validate the research hypotheses. The standardized regression coefficients and their significance levels were then interpreted, and the bootstrapping test was used to verify whether the indirect effects were significant and thus validate the mediating variables. Finally, the research hypotheses were validated.

\section{Results and Discussion}

\subsection{Exploratory Data Analysis}

Data screening showed no missing values, and there were 242 valid cases. In addition, considering the frequencies for qualitative variables (nominal and ordinal), no typing errors were detected, and the items, as designed, have values between 1 and 7.

Regarding the statistical assumptions, tests were performed to evaluate homoscedasticity and normality. Analysis of homoscedasticity through the residuals' drawings was performed, and the results were satisfactory. The multivariate normality analysis is necessary to know the shape of the multivariate distribution of the items, for which Mardia's (1970) kurtosis index, calculated in the AMOS v.23 program, was obtained. The individual results show kurtosis where the data are concentrated in the high values of the scale; a sharp kurtosis is generally intuited, and likewise, the skewness is positive. According to Ayan and Diaz (2008), if the Mardia coefficient exceeds the value of 70, the data do not satisfy the multivariate normality assumption; because in this research, a value of 88.67 was obtained, using the unweighted least squares (ULS) procedure is suggested because it is a procedure that uses polychoric correlations recommended for ordinal scales as is the case in this study (Forero et al., 2009; Yang-Wallentin et al., 2010).

Given the confirmation of the univariate and multivariate non-normal distribution of the data, we sought to identify the possible causes. One of the possible causes of the non-normality of the data could be the existence of outliers. To determine this, the Mahalanobis distance test is applied, which is a widely used criterion for the detection of outliers in multivariate data. Kline (2015) recommended setting a critical value of $p<0.001$. The existence of outliers could be one of the causes of non-normality of the data, which, in turn, could generate Heywood cases (Brown, 2015). Using the Mahalanobis test, 26 outliers with $p$-values $<0.001$ were detected. As already explained, outliers were analyzed, and no problem was found; their removal did not change the non-normality of the data.

\subsection{Descriptive Analysis}

It is important to identify the origin of the participants and to relate this to the classification of the companies according to their turnover and number of workers; $81.73 \%$ of the sample are in Lima, the capital of Peru, while the remaining $18.27 \%$ are in other cities. We performed the chi-square test to account for non-response bias in our survey (Table 2). We did this by comparing the real distribution of SMEs in Peru with the respondent distribution (Malhotra \& Grover, 1998). The result of the test is $\chi^{2}=1.65$, which indicates that there is no significant difference between the survey distribution and the real distribution $(p>0.05)$ which suggests that our sample was not biased towards any region or SME type. 
Table 2. $\chi^{2}$ Test for Survey Bias according to region.

\begin{tabular}{ccccc}
\hline & \multicolumn{2}{c}{ Survey distribution } & \multicolumn{2}{c}{ Real distribution } \\
\hline SME Type & Lima & Outside Lima & Lima & Outside Lima \\
\hline Large SME & $10.58 \%$ & $1.92 \%$ & $4.30 \%$ & $9.00 \%$ \\
Medium SME & $18.27 \%$ & $3.85 \%$ & $8.98 \%$ & $18.74 \%$ \\
Small SME & $52.88 \%$ & $12.50 \%$ & $18.98 \%$ & $40.00 \%$ \\
\hline
\end{tabular}

Source: Own elaboration.

According to the type of manufacturing of the companies, the most frequent is C.10 (food product manufacturing), both in Lima (23\%) and outside the capital, where almost half belong to this category (48.5\%). Companies in categories C.14, C.15, C.17, C.21, C.24, C.26, C.27, C.28, and C.29 were not present outside of Lima.

\subsection{Reliability and Validity}

Reliability has been tested with two indicators: Cronbach's alpha and composite reliability. Although much of the literature favors the use of Cronbach's alpha to test convergent validity, many authors recognize the difficulty that it is influenced by the number of items and by the number of possible responses on the scale because it was created for continuous variables and, in Likert-type scales, this is not the case. Cronbach's alpha shows the reliability based on the correlation between the construct indicators, but it is assumed that the indicators are equally reliable. Because this indicator tends to severely underestimate the reliability of the internal consistency of the SEM model, using different measures, such as composite reliability, is recommended (Henseler et al., 2012). Therefore, we proceeded to validate the composite reliability of the scales for each construct, which should be higher than 0.70 (Boyatzis \& Gaskin, 2010).

Convergent validity means that a set of indicators or items only contribute to explaining the latent variable to which they belong, for which the average variance extracted (AVE) is used. A latent variable with an AVE of at least 0.5 indicates the capacity of the construct to explain more than half of the variance of its indicators on average (Henseler et al., 2012). In addition, discriminant validity was analyzed, which aims to identify whether the observable variables belong to their factor or latent variable and not to another; for this, the matrix criterion was used where the square root of AVE must be greater than the correlations between constructs.

In this study, the validity and reliability test plugin, incorporated in the AMOS v.23 program (Gaskin \& Lim, 2016), was used to determine the reliability and discriminant validity. We constructed the path graph for each construct and calculated its indicators.

Table 3 shows how the composite reliability coefficients exceeded the 0.70 threshold in all factors except LSCS (0.629). The AVE allows verifying convergent validity and contributes to discriminant validity in a measurement model. The factors LSCS, ASCS, CI, and SI do not exceed the suggested threshold of 0.5 . The discriminant validity presents some factors that do not satisfy this situation, given that the value of the diagonal of the matrix (square root of the AVE) is lower than the correlation between some pairs of factors. That is, the square root of AVE for SI is 0.683 and the correlation between SI with CI is 0.746 ; therefore, assumptions are not met, and it suggests that some CI items are highly correlated with SI. This implies that the model should be improved. The table also presents the values of Cronbach's alpha. 
Table 3. Analysis of the Convergent, Discriminant and Reliability Validity of the Initial Model.

\begin{tabular}{|c|c|c|c|c|c|c|c|c|c|}
\hline & $\alpha$ & $\mathrm{CR}$ & AVE & FP & LSCS & ASCS & $\mathrm{CI}$ & II & SI \\
\hline FP & 0.918 & 0.920 & 0.660 & 0.812 & & & & & \\
\hline LSCS & 0.611 & 0.629 & 0.218 & 0.466 & 0.466 & & & & \\
\hline ASCS & 0.683 & 0.737 & 0.311 & 0.427 & 0.681 & 0.558 & & & \\
\hline CI & 0.844 & 0.853 & 0.454 & 0.524 & 0.475 & 0.524 & 0.674 & & \\
\hline II & 0.912 & 0.914 & 0.571 & 0.504 & 0.437 & 0.480 & 0.634 & 0.755 & \\
\hline SI & 0.792 & 0.830 & 0.466 & 0.494 & 0.593 & 0.524 & 0.746 & 0.603 & 0.683 \\
\hline
\end{tabular}

Source: Own elaboration.

However, they will always be lower values than the composite reliability and therefore will not be the subject of further analysis. Using confirmatory factor analysis (CFA), in the next section, we show how to improve the value of these indicators.

\subsection{Structural Equations Model}

A structural equation model comprises two components: a measurement model (basically a CFA) and a structural model (Schreiber et al., 2006). The goodness-of-fit indicators presented for the measurement model, GFI and NFI are 0.923 and 0.918 respectively. The SRMR, which refers to the residuals and should be a value close to zero (less than 0.08), was 0.0678. Additionally, this model presented $\chi^{2}=$ 1526.47 with $g . l .=764$, i.e., $\chi^{2} / g . l .=1.99$, a value that meets the range between 1 and $3(p<$ $\left.1 e^{-52}\right)$.

Construct validity was improved by taking into consideration the results of the index modification (IM) provided by the AMOS program and by observing the factor loadings. After two rounds of analysis, the following final path model was used (Figure 2).

Figure 2. Path Graph Final Measurement Model.

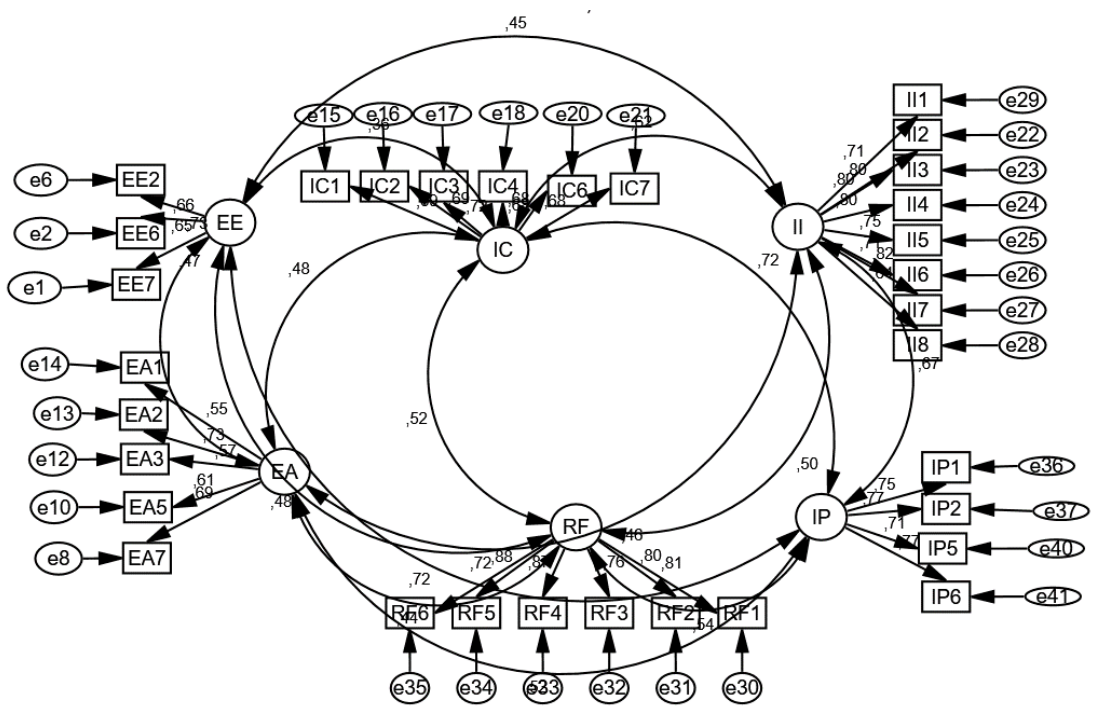

Source: Own elaboration. 
After the adjustments made, an improvement was obtained in the goodness-of-fit indicators, i.e., RFI and NFI were 0.962 and 0.966 respectively, exceeding the thresholds of 0.9 suggested in the literature; the SRMR decreased to a value of 0.0163 , which is satisfactory. Additionally, this model presented $\chi^{2}=527.46$ with $. l .=449$, i.e., $\chi^{2} / g . l .=1.17$, a value that meets the range between 1 and $3(p<0.01)$.

The new reliability and validity indicators showed improvement in relation to the initial model; composite reliability has, in all cases, values higher than 0.70 except LSCS with a value of 0.624 , which can be considered moderate. For AVE, the 0.5 boundary has been considered very strict (Malhotra \& Dash, 2011). Therefore, only the convergence of LSCS could be mentioned as weak. However, it was proved that the indicators are statistically significant, and we proceeded to analyze the discriminant validity. AVE of SI in the improved model was 0.751 higher than the correlations with CI (0.724) and LSCS (0.721), managing to fulfill the discrimination of the factors SI, II, and FP. In the other factors, discriminant validity is not fully satisfied. However, we proceeded to continue to privilege maintaining a greater number of items.

One of the characteristics of these models is that they should be free of Heywood cases, which occur when there are negative variances and/or factor loadings greater than one. During SEM analysis, some factor loadings greater than one were present, and therefore, the coefficients of the relationships that reach the variables CI, II, and SI from LSCS had to be equalized, thus eliminating the problem (Figure 3).

Figure 3. Graph Path of Complete SEM Model.

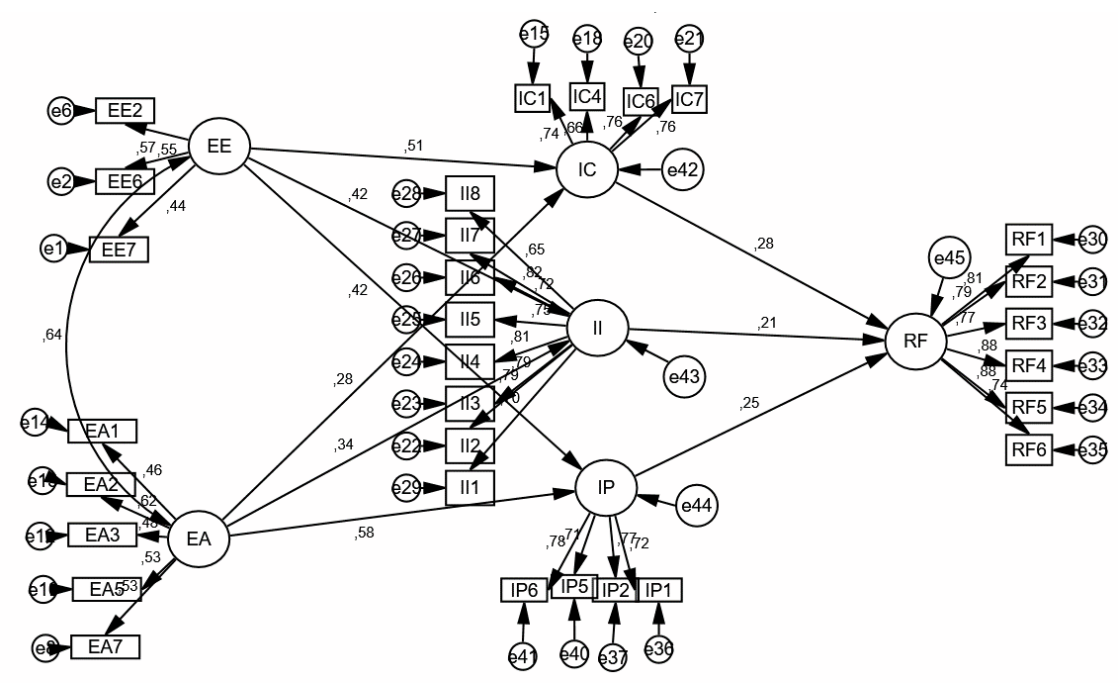

Source: Own elaboration.

Figure 3 shows the final structural model (i.e., definitive relationships and the observable variables that contribute to their respective latent variables); the standardized coefficients or factor loadings and some goodness-of-fit indicators are also shown. In all cases, the indicators were adequate; the NFI (0.953), RFI (0.949), and GFI (0.964) exceeded the threshold of 0.90; in addition, the residuals indicator SRMR (0.069) is less than 0.08. Additionally, this model presented $\chi^{2}=600.40$ with $. l .=$ 398 , i.e., $\chi^{2} / g . l .=1.50$, a value that meets the range between 1 and $3(p<0.001)$. Considering the positive results of the model fit, it is necessary to analyze the statistical significance of the standardized and unstandardized regression coefficients with the bootstrapping technique. 
Table 4. Standardized coefficients of the SEM Model.

\begin{tabular}{|c|c|c|c|c|c|c|}
\hline \multicolumn{3}{|c|}{ Parameter } & \multirow{2}{*}{$\frac{\text { Estimate }}{0.420}$} & \multirow{2}{*}{$\begin{array}{c}\text { Lower } \\
0.269\end{array}$} & \multirow{2}{*}{$\begin{array}{c}\text { Upper } \\
0.616\end{array}$} & \multirow{2}{*}{$\frac{p}{0.002}$} \\
\hline II & $\leftarrow$ & LSCS & & & & \\
\hline II & $\leftarrow$ & ALSC & 0.345 & 0.022 & 0.519 & 0.089 \\
\hline CI & $\leftarrow$ & LSCS & 0.512 & 0.301 & 0.744 & 0.003 \\
\hline SI & $\leftarrow$ & ASCS & 0.579 & 0.469 & 0.689 & 0.004 \\
\hline CI & $\leftarrow$ & ASCS & 0.283 & 0.009 & 0.518 & 0.092 \\
\hline SI & $\leftarrow$ & LSCS & 0.415 & 0.287 & 0.604 & 0.002 \\
\hline FP & $\leftarrow$ & II & 0.211 & -0.08 & 0.42 & 0.164 \\
\hline FP & $\leftarrow$ & $\mathrm{CI}$ & 0.276 & 0.035 & 0.499 & 0.068 \\
\hline FP & $\leftarrow$ & SI & 0.251 & -0.015 & 0.735 & 0.109 \\
\hline
\end{tabular}

Source: Own elaboration.

Table 4 shows the constructs' relationships, loading estimation values, their confidence intervals, and $p$-values. It is concluded that construct II does not significantly explain FP $(p>0.05)$. SI does not significantly impact FP either $(p>0.01)$; the CI construct explains significantly the relationship with FP $(p<0.01)$. The other relationships are statistically significant at 95\%, except for LSCS to CI, which is significant at $90 \%$.

Additionally, it was detected that LSCS is highly correlated with ASCS; the coefficient found was $0.645(p<0.05)$. With respect to the coefficients of determination, all of them were found to be statistically significant; $39.7 \%$ of the variance of FP is explained by the model, which is considered a moderately high explanation for SEM. SI is explained $81.7 \%$ by the ASCS and LSCS factors, while II is $48.2 \%$ explained by the same ASCS and LSCS latent variables. This indicates that the direct effects between the exogenous and mediating variables were significant.

Therefore, the direct hypotheses related to the quantitative study can be validated:

H1: Lean supply chain strategy (LSCS) is positively related to internal integration (II).

Given the $p$-value, it can be stated that indeed lean supply chain strategy does have a direct and positive effect on II, with a positive coefficient of 0.420 and a $p$-value $=0.002$. Therefore, $H 1$ is accepted.

H2: Lean supply chain strategy (LSCS) is positively related to customer integration (CI).

It can be stated that indeed lean supply chain strategy has a direct positive effect on CI since the coefficient is positive $(0.5120)$ and the $p$-value $=0.003$. Therefore, $H 2$ is accepted.

H3: Lean supply chain strategy (LSCS) is positively related to supplier integration (SI). 
The tendency is maintained in affirming that indeed the lean supply chain strategy does have a direct positive effect on SI given that the coefficient is positive (0.415) and the $p$-value $=0.002$. Therefore, $H 3$ is accepted.

H4: Agile supply chain strategy (ASCS) is positively related to internal integration (II).

Agile supply chain strategy has a direct positive effect on II (coefficient of 0.345 ), with $90 \%$ confidence. Therefore, $H 4$ is accepted.

H5: Agile supply chain strategy (ASCS) is positively related to customer integration (CI).

Agile supply chain strategy affects CI performance (coefficient of 0.283 ), with $90 \%$ confidence. Therefore, $H 5$ is accepted.

H6: Agile supply chain strategy (ASCS) is positively related to supplier integration (SI).

It can be stated that indeed agile supply chain strategy does have a direct positive effect on SI because the coefficient is positive (0.579) and the $p$-value $=0.004$. Therefore, $H 6$ is accepted.

H7: Internal integration (II) is positively related to financial performance.

No significant direct effect of II on financial performance was found because its significance $p$-value $>0.05(0.164)$. Therefore, $H 7$ is not accepted.

H8: Customer integration (CI) is positively related to financial performance.

Integration with customers affects financial performance (coefficient of 0.276 ) at $90 \%$ confidence. Therefore, $H 8$ is accepted.

H9: Supplier integration (SI) is positively related to financial performance.

Integration with suppliers presents a $p$-value $=0.109$, close to $90 \%$ significance. Therefore, it can be stated that the hypothesis is not satisfied at $95 \%$. Therefore, $H 9$ is not accepted.

The study showed that no matter what type of supply chain strategy is used, customer integration is important for the organization as demonstrated in hypothesis $H 8$; this is in line with previous work in this field (Qi et al., 2017). Additionally, our findings suggest that lean SCS requires greater integration with customers than with suppliers and internal integration itself; this is in contrast to the work of Choi and $\mathrm{Wu}(2009)$ in which lean SCS requires very close relationships with suppliers. Possible explanations are, first, that our result can be justified by the close relationship that exporting SMEs develop with their customers, and second, that many SMEs operate not entirely as agile or lean companies. Such companies have been characterized in the literature as having a hybrid supply chain or leagile (Christopher et al., 2006). This new construct is characterized by the appearance of a decoupling point which determines where the lean emphasis stops and the agile emphasis begins. This construct can act as an unobserved cofounding factor in our model which presents an interesting avenue for future research. On the other hand, it was found that agile SCS requires a higher level of integration with suppliers than with customers; this finding is consistent with that of Lee (2004) and Swafford et al. (2006), which is valid given the level of relationship that companies develop with their suppliers, especially when flexibility is important in order fulfillment. These types of relationships enable firms to influence their supplier manufacturing process. An agile SCS should explore various supplier and logistics network options to ensure rapid response to changing demand and supply conditions (Stavrulaki \& Davis, 2010). Another important finding is that the need for internal integration is greater in the case of lean SCS than in agile SCS, which is consistent with studies conducted in China on this 
topic. Similar or different results cannot be validated with countries in the region, as this is, to the best of the researcher's knowledge, the first study conducted on this topic in Latin America.

Contrary to expectation, internal integration is not related to financial performance (Flynn et al., 2010; Qi et al., 2017). There are two possible explanations for this. First, companies in our sample have achieved a relatively high level of internal integration so that its effects on financial performance at such a level are minuscule. This is supported by the fact that in recent years the implementation of information systems for management has been widespread (Olhager \& Selldin, 2003). Second, the information was collected during the pandemic, which could have affected the response of the interviewees. This evidence points out that internal integration might have a mediating role in financial performance either through customer or supplier integration which indicates a necessity for new research into these effects. In this research, the construct external integration was divided into integration with suppliers and integration with customers, to extend the analysis to the relationship of these constructs with financial performance. It was determined that integration with customers is positively related to financial performance; this implies that information sharing and follow-up for feedback with customers contribute to financial performance in serving customers. This finding is similar to that of Koufteros et al. (2005) which showed that CI can enhance financial performance through quality and innovation performance and with $\mathrm{Yu}$ et al. (2013), who further established the mediating effect that customer satisfaction has on this relationship. Integration with suppliers does not influence organizational performance. This finding is consistent with Flynn et al. (2010); however, Zhao et al. (2008) pointed out that this may be because the effect of suppliers on financial performance is nonlinear. Previous studies have been inconsistent in their findings of the relationship between external integration and financial performance. We present two possible explanations. First, supplier integration requires heavy investments such as information systems, supplier quality assurance, and human resources for process coordination which can lead to diminished financial performance. Second, supply chains in the region are more focused on customer integration than supplier integration as pointed out in surveys conducted by Tanco et al. (2018).

$\mathrm{Yu}$ et al. (2013) noted, for example, that external integration, understood as integration with customers and integration with suppliers, does not have a positive relationship with financial performance, probably due to the mediation or moderation of some other variable. Flynn et al. (2010) provided preliminary evidence pointing to the importance of including internal integration in the development of supply chain integration patterns, which provides a vital link between customer integration and supplier integration, without which firms cannot reap the full benefits of their integration efforts. The findings of Flynn et al. (2010) could not be corroborated in this research. However, it was found that in the model proposed, financial performance is explained by $39.7 \%$, a value considered moderately high for a system of structural equations. Supplier integration, internal integration, and customer integration are $81.7 \%, 48.2 \%$, and $52.9 \%$ explained by the factors lean SCS and agile SCS. This indicates that the direct effects between the exogenous variables and the mediating variables were significant. In addition, the variables lean SCS and agile SCS contribute to explaining financial performance through the mediating variables supplier integration, internal integration, and customer integration. In all cases, the models had adequate goodness-of-fit indicators.

\section{Theoretical and Managerial Implications}

Research in supply chain management is highly theoretical (Naim \& Gosling, 2011), meaning there is a lack of empirical research in the field. Our study contributes to filling this gap by investigating the role of supply chain integration in Peruvian export SMEs. Likewise, the role of supply chain management in SMEs is largely not understood because of the lack of research in this area (Kull et al., 2018). Our study helps to understand the different challenges and opportunities that supply chain management entails for SMEs. We remark that this research offers a complete vision of the panorama of supply chain in SMEs and that further and deeper studies such as longitudinal or randomized studies are needed which can broaden the range of phenomena studied and give rise to the creation of new 
theoretical perspectives and constructs. Furthermore, our study of Peruvian export SMEs contributes to the knowledge of supply chain management in developing countries which is lacking especially in Latin America (Tanco et al., 2018). This study also has theoretical implications and suggests lines of research that will help to extend the knowledge of SCS and SCI and their relationship with the financial performance of the companies indicated. Although the study was conducted for exporting companies, the methodology used can be replicated for companies that operate only in local markets.

One reason neither internal integration (II) nor supplier integration (SI) fails to influence financial performance (FP) directly is that they require various levels of investment not directly related to the main objective of a supply chain (to provide maximum value to the customer) which is necessarily customer oriented. Key suppliers and customers are the primary source of information which is a key input in the organizational decision-making process and necessary to attain financial performance. That is why we argue that the constructs II and SI are necessary for companies as they represent capabilities which they are required to use to create financial value. If firms have a weak internal integration, such as poor internal data integration, less communication among functions, or no teamwork, it will be difficult for them to adequately maintain good relations with customers and suppliers. Given the earlier work that argues and provides partial support in direct contrast with our arguments, our findings are intriguing and complementary.

Currently, organizations determinedly attempt to obtain competitive edge, and this research suggests, which we present as our major managerial implication, that depending on which operation strategies are used, companies should intentionally develop different integration capabilities. Companies with a lean operational focus should strive to develop greater integration with customers. Likewise, companies with an agile operational focus should strive to develop greater integration with suppliers. Internal integration should be developed for both types of operational strategies, but lean companies should pay special attention to it. In addition, managers should work together to design supply chain strategies and supply chain integration and pay attention to how they are linked. Our findings indicate that companies wishing to apply concepts of supply chain integration, but which are limited in resources, should start with customer integration as is the construct most directly related to financial performance. When no such constraints exist, all three constructs of supply chain integration should be developed. The results obtained in this research have implications for business managers who want to learn about the effects that the implementation of SCS have on a company's financial performance.

\section{Conclusion and scope of future research}

This research focused on analyzing a holistic model between supply chain strategies, their integration, and the financial performance of an organization. The study was applied to Peruvian export SMEs, according to ISIC REV. 4.0. This work had the peculiarity of having been carried out during the COVID-19 pandemic, which significantly affected all companies and highlighted the role that the supply chain plays both locally and globally.

The descriptive analysis of the data allowed us to obtain the most relevant characteristics of the participants in this study. After looking for sources of bias and testing the validity of our framework, a structural equation model was developed to test the nine hypotheses. The different models were evaluated through goodness-of-fit indicators. Seven of the nine proposed hypotheses were accepted. Findings indicate that companies should prioritize their integration effort depending on the type of supply chain strategy they use.

Likewise, we demonstrate empirical evidence that customer integration is directly related to a firm's financial performance, for which we have also presented ample evidence in the literature. Through effective relationships with customers, firms are more likely to acquire and absorb knowledge quickly and effectively, which leads to competitive advantage. It seems that the lack of direct effect of 
internal integration is because internal integration is a construct that affects financial performance indirectly only with a mediating relationship with customer and supplier integration, which could not have been corroborated in this research as our model did not include this effect, but it is a relationship which has been found for other types of performance in other research (Jajja et al., 2016).

This study fills two gaps in the literature. First, there is a tendency not to study SMEs in the supply chain management field, and our study serves to fill this gap in the literature. Second, supply chain management research in Latin America is lacking, and our study serves to fill this gap in the literature. Our study also extends the framework developed by Qi et al. (2017) by separating the construct of external integration into customer integration and supplier integration which allowed us to find the importance of customer integration to a firm's financial performance, a result which could not be corroborated in the original framework.

An extensive review of the literature revealed no studies of this type in the region, and most of the research conducted is from first-world countries or developing countries with economies that are much more developed than those of Latin America. Therefore, this study responds to the need to find answers to the development of supply chain strategies and the generation of competitive advantage in Peruvian export-manufacturing SMEs. This research is based on the same dynamic capabilities of a company that are transferable to the supply chain context (Qi et al., 2017).

\section{Recommendations for future research}

A clear understanding of the meaning and implications that supply chain strategies have in organizations in the region is still emerging, so more studies in other Latin American countries is recommended. Instruments that are in line with the new realities, regarding new technologies, should be evaluated.

Because the study was conducted for Peruvian export SMEs according to ISIC REV. 4.0, it is difficult to generalize the results obtained, so it is recommended that future research broaden the spectrum to other types of companies. In addition, the timeframe of the study is cross-sectional, so longitudinal studies are recommended.

Neither internal integration (II) nor supplier integration (SI) directly relates to financial performance (FP), but we hypothesize that they might be related indirectly through other constructs which can serve a mediating role such as operation performance and flexibility; we leave the study of this relationship to future research.

As the data were collected only from Peruvian export SMEs, future studies can broaden their scope by collecting data from all supply chain partners, including suppliers, manufacturers, and customers. The development of biosecurity policies, due to the COVID19 pandemic, could alter factors that influence the supply chain from operations strategies, which would mean defining new measurement instruments for them; this could be investigated and included in the new models that will be proposed in the future.

\section{References}

Acar, A.Z., Zehir, C., \& Tanriverdi, H. (2006). Identifying organizational capabilities as predictors of growth and business performance. The Business Review, Cambridge, 5, 109-116.

Ahmad, S., \& Schroeder, R.G. (2001). The impact of electronic data interchange on delivery performance. Production and Operations Management, 10(1), 16-30. https://doi.org/10.1111/j.1937-5956.2001.tb00065.x 
Alfalla-Luque, R., \& Medina-López, C. (2009). Supply chain management: Unheard of in the 1970s, core to today's company. Business History, 51(2), 202-221. https://doi.org/10.1080/00076790902726558

Araya, A. (2016). El Proceso de Internacionalización de Empresas | Tec Empresarial. https://revistas.tec.ac.cr/index.php/tec_empresarial/article/view/653

Ayán, M.N.R., \& Díaz, M.Á.R. (2008). Atenuación de la asimetría y de la curtosis de las puntuaciones observadas mediante transformaciones de variables: Incidencia sobre la estructura factorial. Psicológica, 29(2), 205-227.

Boyatzis, R.E., \& Gaskin, J. (2010). A technical note on the ESCI and ESCI-U: Factor structure, reliability, convergent and discriminant validity using EFA and CFA. Boston: Hay Group.

Brown, T.A. (2015). Confirmatory factor analysis for applied research (2 $2^{\text {nd }}$ ed.). Guilford: Guilford Publication.

Chen, I.J., \& Paulraj, A. (2004). Understanding supply chain management: Critical research and a theoretical framework. International Journal of Production Research, 42(1), 131-163. https://doi.org/10.1080/00207540310001602865

Choi, T.Y., \& Wu, Z. (2009). Triads in supply networks: Theorizing buyer-supplier-supplier relationships. Journal of Supply Chain Management, 45(1), 8-25. https://doi.org/10.1111/j.1745493X.2009.03151.x

Christopher, M. (2000). The agile supply chain: Competing in volatile markets. Industrial Marketing Management, 29(1), 37-44. https://doi.org/10.1016/S0019-8501(99)00110-8

Christopher, M., Peck, H., \& Towill, D. (2006). A taxonomy for selecting global supply chain strategies. The International Journal of Logistics Management, 17(2), 277-287. https://doi.org/10.1108/09574090610689998

De Toni, A., \& Tonchia, S. (2001). Performance measurement systems. Models, characteristics and measures. International Journal of Operations \& Production Management, 21(1/2), 46-71. https://doi.org/10.1108/01443570110358459

Ellinger, A.E., Daugherty, P.J., \& Keller, S.B. (2000). The relationship between marketing/logistics interdepartmental integration and performance in US manufacturing firms: An empirical study. Journal of Business Logistics, 21(1), 1-22.

Fisher, M. (1997). What is the right supply chain for your product? Harvard Business Review, 75, 105116. https://hbr.org/1997/03/what-is-the-right-supply-chain-for-your-product

Flynn, B.B., Huo, B., \& Zhao, X. (2010). The impact of supply chain integration on performance: A contingency and configuration approach. Journal of Operations Management, 28(1), 58-71. https://doi.org/10.1016/j.jom.2009.06.001

Forero, C.G., Maydeu-Olivares, A., \& Gallardo-Pujol, D. (2009). Factor analysis with ordinal indicators: A Monte Carlo study comparing DWLS and ULS estimation. Structural Equation Modeling: $\quad A \quad$ Multidisciplinary Journal, $16(4), \quad 625-641$. https://doi.org/10.1080/10705510903203573

Frohlich, M.T., \& Westbrook, R. (2001a). Arcs of integration: An international study of supply chain strategies. Journal of Operations Management, 19(2), 185-200. https://doi.org/10.1016/S02726963(00)00055-3 
Frohlich, M.T., \& Westbrook, R. (2001b). Arcs of integration: An international study of supply chain strategies. Journal of Operations Management, 19(2), 185-200. https://doi.org/10.1016/S02726963(00)00055-3

Garcés, B.L.S., \& Landa, S.D.R. (2019). Análisis de los determinantes y costos de la informalidad en las pequeñas empresas: un estudio empírico para el Perú / Analysis of determinants and costs of informality in small businesses: An empirical study for Peru. Revista de Métodos Cuantitativos para la Economía y la Empresa, 27, 156-165.

Gaskin, J., \& Lim, J. (2016). Master validity tool. AMOS Plugin In: Gaskination's StatWiki.

Gunasekaran, A., \& Yusuf, Y.Y. (2002). Agile manufacturing: A taxonomy of strategic and technological imperatives. International Journal of Production Research, 40(6), 1357-1385. https://doi.org/10.1080/00207540110118370

Henseler, J., Ringle, C.M., \& Sarstedt, M. (2012). Using partial least squares path modeling in advertising research: Basic concepts and recent issues. In S. Okazaki (Ed.), Handbook of research $\begin{array}{llll}\text { on international } & \text { advertising 252-277). }\end{array}$ https://www.elgaronline.com/view/edcoll/9781848448582/9781848448582.00023.xml

Holt, D.T., Madison, K., \& Kellermanns, F.W. (2017). Variance in family members' assessments: The importance of dispersion modeling in family firm research. Family Business Review, 30(1), 61-83. https://doi.org/10.1177/0894486516673700

Hsu, C.-C., Kannan, V.R., Tan, K.-C., \& Leong, G.K. (2008). Information sharing, buyer-supplier relationships, and firm performance. International Journal of Physical Distribution \& Logistics Management, 38(4), 296-310. https://doi.org/10.1108/09600030810875391

Huh, S., Yook, K.-H., \& Kim, I. (2008). Relationship between organizational capabilities and performance of target costing: An empirical study of Japanese companies. Journal of International Business Research, 7(1), 91-107.

Humphrey, J., \& Schmitz, H. (2002). Developing country firms in the world economy: Governance and upgrading in global value chains (INEF Report No. 61). Duisburg: University of Duisburg.

Huo, B. (2012). The impact of supply chain integration on company performance: An organizational capability perspective. Supply Chain Management: An International Journal, 17(6), 596-610. https://doi.org/10.1108/13598541211269210

Huo, B., Han, Z., Zhao, X., Zhou, H., Wood, C.H., \& Zhai, X. (2013). The impact of institutional pressures on supplier integration and financial performance: Evidence from China. International Journal of Production Economics, 146(1), 82-94. https://doi.org/10.1016/j.ijpe.2013.01.013

Huo, B., Qi, Y., Wang, Z., \& Zhao, X. (2014). The impact of supply chain integration on firm performance: The moderating role of competitive strategy. Supply Chain Management: An International Journal, 19(4), 369-384. https://doi.org/10.1108/SCM-03-2013-0096

Hussain, M., Ajmal, M.M., Khan, M., \& Saber, H. (2015). Competitive priorities and knowledge management: An empirical investigation of manufacturing companies in UAE. Journal of Manufacturing Technology Management, 26(6), 791-806. https://doi.org/10.1108/JMTM-03-20140020

Jacobs, F.R., Chase, R.B., \& Lummus, R.R. (2014). Operations and supply chain management. New York: McGraw-Hill/Irwin. 
Jajja, M.S.S., Chatha, K.A., \& Farooq, S. (2018). Impact of supply chain risk on agility performance: Mediating role of supply chain integration. International Journal of Production Economics, 205, 118-138. https://doi.org/10.1016/j.ijpe.2018.08.032

Jajja, M.S.S., Kannan, V.R., Brah, S.A., \& Hassan, S.Z. (2016). Supply chain strategy and the role of suppliers: Evidence from the Indian sub-continent. Benchmarking: An International Journal, 23(7), 1658-1676. https://doi.org/10.1108/BIJ-06-2014-0058

Jasti, N.V.K., \& Kodali, R. (2015). A critical review of lean supply chain management frameworks: Proposed framework. Production Planning \& Control, 26(13), 1051-1068. https://doi.org/10.1080/09537287.2015.1004563

Kim, S.W. (2009). An investigation on the direct and indirect effect of supply chain integration on firm performance. International Journal of Production Economics, 119(2), 328-346. https://doi.org/10.1016/j.ijpe.2009.03.007

Kline, R.B. (2015). Principles and practice of structural equation modeling (4 ${ }^{\text {th }}$ ed.). New York: Guilford.

Koufteros, X., Vonderembse, M., \& Jayaram, J. (2005). Internal and external integration for product development: The contingency effects of uncertainty, equivocality, and platform strategy. Decision Sciences, 36(1), 97-133. https://doi.org/10.1111/j.1540-5915.2005.00067.x

Kull, T.J., Kotlar, J., \& Spring, M. (2018). Small and medium enterprise research in supply chain management: The case for single-respondent research designs. Journal of Supply Chain Management, 54(1), 23-34. https://doi.org/10.1111/jscm.12157

La Porta, R., Lopez-de-Silanes, F., \& Shleifer, A. (1999). Corporate ownership around the world. The Journal of Finance, 54(2), 471-517. https://doi.org/10.1111/0022-1082.00115

Lee, H. L. (2004). The triple-A supply chain. Harvard Business Review, 82(10), 102-113.

Liu, Y., \& Liang, L. (2015). Evaluating and developing resource-based operations strategy for competitive advantage: An exploratory study of Finnish high-tech manufacturing industries. International Journal of Production Research, 53(4), 1019-1037. https://doi.org/10.1080/00207543.2014.932936

Malhotra, M.K., \& Grover, V. (1998). An assessment of survey research in POM: From constructs to theory. Journal of Operations Management, 16(4), 407-425. https://doi.org/10.1016/S02726963(98)00021-7

Malhotra, N.K., \& Dash, S. (2011). Marketing research an applied orientation. London: Pearson.

Manosalvas, V. (2018). Estilos de liderazgo e intercambio de conocimiento: Análisis del efecto mediador del clima de aprendizaje organizacional [Doctoral dissertation, Pontificia Universidad Católica del Perú]. http://tesis.pucp.edu.pe/repositorio/handle/20.500.12404/10237

Mardia, K.V. (1970). Measures of multivariate skewness and kurtosis with applications. Biometrika, 57(3), 519-530. https://doi.org/10.1093/biomet/57.3.519

Marin-Garcia, J.A., Alfalla-Luque, R., \& Medina-López, C. (2014). Internal and external supply chain integration: Construct definition and validation. In J. C. Prado-Prado \& J. García-Arca (Eds.), Annals of industrial engineering 2012 (pp. 115-122). Springer. https://doi.org/10.1007/978-1-4471-5349$8 \_14$ 
Naim, M.M., \& Gosling, J. (2011). On leanness, agility and leagile supply chains. International Journal of Production Economics, 131(1), 342-354. https://doi.org/10.1016/j.ijpe.2010.04.045

Narasimhan, R., \& Kim, S.W. (2002). Effect of supply chain integration on the relationship between diversification and performance: Evidence from Japanese and Korean firms. Journal of Operations Management, 20(3), 303-323. https://doi.org/10.1016/S0272-6963(02)00008-6

Olhager, J., \& Selldin, E. (2003). Enterprise resource planning survey of Swedish manufacturing firms. European Journal of Operational Research, 146(2), 365-373. https://doi.org/10.1016/S03772217(02)00555-6

Qi, Y., Huo, B., Wang, Z., \& Yeung, H.Y.J. (2017). The impact of operations and supply chain strategies on integration and performance. International Journal of Production Economics, 185, 162-174. https://doi.org/10.1016/j.ijpe.2016.12.028

Qrunfleh, S., \& Tarafdar, M. (2013). Lean and agile supply chain strategies and supply chain responsiveness: The role of strategic supplier partnership and postponement. Supply Chain Management: An International Journal, 18(6), 571-582. https://doi.org/10.1108/SCM-01-20130015

Quesada, G., Rachamadugu, R., Gonzalez, M., \& Martinez, J.L. (2008). Linking order winning and external supply chain integration strategies. Supply Chain Management: An International Journal, 13(4), 296-303. https://doi.org/10.1108/13598540810882189

Ralston, P.M., Blackhurst, J., Cantor, D.E., \& Crum, M.R. (2015). A structure-conduct-performance perspective of how strategic supply chain integration affects firm performance. Journal of Supply Chain Management, 51(2), 47-64. https://doi.org/10.1111/jscm.12064

Rodríguez, H.A.R., \& Figueroa, L.S. (2013). Capacidades dinámicas, una fuente de ventaja competitiva. Criterio Libre, 11(19), 245-261. https://doi.org/10.18041/19000642/criteriolibre.2013v11n 19.1110

Roh, J., Hong, P., \& Min, H. (2014). Implementation of a responsive supply chain strategy in global complexity: The case of manufacturing firms. International Journal of Production Economics, 147, 198-210. https://doi.org/10.1016/j.ijpe.2013.04.013

Roncal, A. (2019). Las medianas empresas se ponen al día en digitalización. Semana Económica. https://semanaeconomica.com/management/digitalizacion/363452-las-medianas-se-ponen-al-dia

Ruiz-Torres, A.J., Mahmoodi, F., \& Ayala-Cruz, J. (2012). Supply chain management research in Latin America: A review. Supply Chain Forum: An International Journal, 13(1), 20-36. https://doi.org/10.1080/16258312.2012.11517285

Saeed, K., Malhotra, M., \& Grover, V. (2005). Examinig the impact of interorganizational system on process efficiency and sourcing leverage in buyer-supplier dyads. Decision Sciences, 36(3), 365396.

Saini, A., \& Johnson, J.L. (2005). Organizational capabilities in e-commerce: An empirical investigation of e-brokerage service providers. Journal of the Academy of Marketing Science, 33(3), 360-375. https://doi.org/10.1177/0092070305276150

Schoenherr, T., \& Swink, M. (2012). Revisiting the arcs of integration: Cross-validations and extensions. Journal of Operations Management, 30(1-2), 99-115. https://doi.org/10.1016/j.jom.2011.09.001 
Schreiber, J.B., Nora, A., Stage, F.K., Barlow, E.A., \& King, J. (2006). Reporting structural equation modeling and confirmatory factor analysis results: A review. The Journal of Educational Research, 99(6), 323-338. https://doi.org/10.3200/JOER.99.6.323-338

Shavarini, S.K., Salimian, H., Nazemi, J., \& Alborzi, M. (2013). Operations strategy and business strategy alignment model (case of Iranian industries). International Journal of Operations \& Production Management, 33(9), 1108-1130. https://doi.org/10.1108/IJOPM-12-2011-0467

Shou, Y., Hu, W., Kang, M., Li, Y., \& Park, Y.W. (2018). Risk management and firm performance: The moderating role of supplier integration. Industrial Management \& Data Systems, 118(7), 13271344. https://doi.org/10.1108/IMDS-09-2017-0427

SIPC Market Intelligence. (2019). Nota de prensa exportaciones Perú. Commission for the Promotion of Peru for Exports and Tourism. https://exportemos.pe/inteligencia-para-exportar/publicaciones-ymultimedia

Skinner, W. (1969, May 1). Manufacturing-Missing link in corporate strategy. Harvard Business Review, 47(3), 136-145. https://hbr.org/1969/05/manufacturing-missing-link-in-corporate-strategy

Stank, T.P., Keller, S.B., \& Daugherty, P.J. (2001). Supply chain collaboration and logistical service performance. Journal of Business Logistics, 22(1), 29-48. https://doi.org/10.1002/j.21581592.2001.tb00158.x

Stavrulaki, E., \& Davis, M. (2010). Aligning products with supply chain processes and strategy. The International Journal of Logistics Management, 21(1), 127-151. https://doi.org/10.1108/09574091011042214

Swafford, P.M., Ghosh, S., \& Murthy, N.N. (2006). A framework for assessing value chain agility. International Journal of Operations \& Production Management, 26(2), 118-140. https://doi.org/10.1108/01443570610641639

Tanco, M., Escuder, M., Heckmann, G., Jurburg, D., \& Velazquez, J. (2018). Supply chain management in Latin America: Current research and future directions. Supply Chain Management: An International Journal, 23(5), 412-430. https://doi.org/10.1108/SCM-07-2017-0236

Thakkar, J., \& Deshmukh, S.G. (2008). Supply chain management in SMEs: Development of constructs and propositions. Asia Pacific Journal of Marketing and Logistics, 20, 97-131. https://doi.org/10.1108/13555850810844896

United Nations Department of Economic and Social Affairs, Statistics Division. (2008). International standard industrial classification of all economic activities (Statistical papers Series M No. 4/Rev.4). https://unstats.un.org/unsd/publication/seriesm/seriesm_4rev4e.pdf

Urmeneta, R. (2016). Dinámica de las empresas exportadoras en América Latina: El aporte de las PYMES. CEPAL. https://www.cepal.org/es/publicaciones/40296-dinamica-empresas-exportadorasamerica-latina-aporte-pymes

Verona, G. (1999). A resource-based view of product development. Academy of Management Review, 24(1), 132-142. https://doi.org/10.5465/amr.1999.1580445

Vickery, S.K., Jayaram, J., Droge, C., \& Calantone, R. (2003). The effects of an integrative supply chain strategy on customer service and financial performance: An analysis of direct versus indirect relationships. Journal of Operations Management, 21(5), 523-539. https://doi.org/10.1016/j.jom.2003.02.002 
Ward, P.T., Duray, R., Keong Leong, G., \& Sum, C.-C. (1995). Business environment, operations strategy, and performance: An empirical study of Singapore manufacturers. Journal of Operations Management, 13(2), 99-115. https://doi.org/10.1016/0272-6963(95)00021-J

Won Lee, C., Kwon, I.G., \& Severance, D. (2007). Relationship between supply chain performance and degree of linkage among supplier, internal integration, and customer. Supply Chain Management: An International Journal, 12(6), 444-452. https://doi.org/10.1108/13598540710826371

Yang-Wallentin, F., Jöreskog, K.G., \& Luo, H. (2010). Confirmatory factor analysis of ordinal variables with misspecified models. Structural Equation Modeling: A Multidisciplinary Journal, 17(3), 392423. https://doi.org/10.1080/10705511.2010.489003

Yu, W., Jacobs, M.A., Salisbury, W.D., \& Enns, H. (2013). The effects of supply chain integration on customer satisfaction and financial performance: An organizational learning perspective. International Journal of Production Economics, 146(1), 346-358. https://doi.org/10.1016/j.ijpe.2013.07.023

Zhao, X., Huo, B., Flynn, B.B., \& Yeung, J.H.Y. (2008). The impact of power and relationship commitment on the integration between manufacturers and customers in a supply chain. Journal of Operations Management, 26(3), 368-388. https://doi.org/10.1016/j.jom.2007.08.002

\section{APPENDIX A}

Table A1. Factor Operationalization.

\section{Lean SCS}

Agile SCS

Internal Integration
- (LSCS1) Our supply chain provides products with predictable demand.

- (LSCS2) Our supply chain reduces waste as much as possible.

- (LSCS3) Our supply chain reduces costs through high volume production.

- (LSCS4) Our supply chain provides standardized products to customers.

- (LSCS5) Our supply chain maintains a long and stable relationship with a small number of suppliers.

- (LSCS6) Our supply chain selects suppliers based on their cost and quality performance.

- (LSCS7) The structure of our supply chain rarely changes.

- (ASCS1) Our supply chain constantly faces customer-demand volatility.

- (ASCS2) Our supply chain responds quickly to the changing market environment.

- (ASCS3) Our supply chain maintains increased storage capacity to respond to market volatility.

- (ASCS4) Our supply chain provides customized products to customers.

- (ASCS5) Our supply chain selects suppliers based on their performance in flexibility and responsiveness.

- (ASCS6) Our supply chain needs to maintain a fast and flexible relationship with many suppliers.

- (ASCS7) The structure (capacity) of our supply chain changes frequently to cope with market volatility.

- (II1) We integrate data between internal functions through an information network.

- (II2) We have an information system that integrates all functional areas.

- (II3) We monitor inventory levels in the chain in real time.

- (II4) We consult in real time operational data related to logistics.

- (II5) We integrate information into the production process. 
- (II6) We manage inventory in a systematic way.

- (II7) We have a system that integrally facilitates the interaction between production and sales.

- (II8) We hold meetings with established frequencies between functional areas.

- (SI1) We follow up with customers to obtain feedback.

- (SI2) We implement computerized systems for customers to manage their orders.

Client

Integration

Supplier

Integration

Financial

Performance
- (SI3) Our direct link with customers is through a computer network.

- (SI4) We exchange market information with customers.

- (SI5) We establish contacts with established frequency with customers.

- (SI6) We are agile in processing orders.

- (SI7) We have high levels of communication with customers.

- (SI1) We exchange information with suppliers through information technology.

- (SI2) We have a strategic relationship with our main suppliers.

- (SI3) There are levels of supplier participation in the design stage.

- (SI4) We have levels of supplier participation in the procurement and production process.

- (SI5) We have a fast-ordering system.

- (SI6) There are constant purchasing levels through the supplier network.

- (FP1) Return on investments (ROI).

- (FP2) Return on sales (ROS).

- (FP3) Market share.

- (FP4) Return on investment (ROI) growth.

- (FP5) Growth in return on sales (ROS).

- (FP6) Growth in market share.

Source: Own elaboration. 